\title{
Hepatitis B Virus-Associated Nephropathy
}

\author{
Rajendra Bhimma Hoosen Mohamed Coovadia \\ Department of Paediatrics and Child Health, Nelson R. Mandela School of Medicine, University of Natal, \\ Durban, South Africa
}

\section{Key Words}

Hepatitis B virus · Nephrotic syndrome · Membranous nephropathy $\cdot$ Proteinuria $\cdot$ Interferon- $\alpha 2 b$

\begin{abstract}
A direct causal association between hepatitis $B$ virus (HBV) infection and the development of nephropathy remains controversial. Epidemiological studies have shown that chronic carriage of HBV in some individuals (particularly children) leads to the development of nephrotic syndrome with a strong male predominance, the commonest histological type being membranous nephropathy (MN). Spontaneous clearance of HBV antigens (particularly the $\mathrm{HBeAg}$ ) leads to abrogation of proteinuria. The isolation of immune complexes in the kidney suggests that the pathogenesis of the disease may have an immune-complex basis. Recent studies showing expression of HBV viral antigens in kidney tissue suggest direct viral-induced pathological alterations and chronic immunologic injury. Biosocial studies have detected no correlation between HBV carriage and proteinuria using both quantitative and qualitative urinary protein analysis. Genetic studies of HLA class I and II genes showed a predisposition to MN but no similar correlation in those with milder degrees of proteinuria. These findings suggest that milder proteinuria is unrelated to HBV carriage or genetic factors but the development of nephropathy,
\end{abstract}

\section{KARGER}

Fax +4161306 1234

E-Mail karger@karger.ch

www. karger.com
(C) 2004 S. Karger AG, Basel

0250-8095/04/0242-0198\$21.00/0

Accessible online at:

www.karger.com/ajn particularly $\mathrm{MN}$, in patients with chronic HBV carriage (HBsAg and/or HBV DNA positive) is based on an interaction of virus and host factors. Although the natural history of the disease tends to remission with preservation of renal function, there is considerable morbidity and a small but significant mortality. Use of naturally occurring cytokines (such as interferon- $\alpha 2 b$ ) and other candidate therapies accelerates clearance of the virus and proteinuria. The most effective tool in reducing the incidence of the disease is the use of HBV vaccines.

Copyright @ 2004 S. Karger AG, Basel

\section{Introduction}

A variety of extrahepatic disorders, one of the commonest being hepatitis B virus (HBV)-associated nephropathy [1], may appear in persons chronically infected with HBV [2-4]. Immune complexes mediate most of these injuries [2-4].

In 1971, Combes et al. [2] were the first to describe a 53-year-old man with membranous glomerulonephritis due to glomerular deposition of Australian-antigen-containing immune complexes. Subsequently, Takekoski et al. [5] reported 2 children with $\mathrm{HBV}$ and membranous nephropathy $(\mathrm{MN})$; $\mathrm{HBeAg}$ together with $\mathrm{IgG}$ and $\beta 1 \mathrm{C}$ were deposited along the glomerular capillary wall. Different histological types of glomerular lesions have been 
Fig. 1. Epidemiology of hepatitis $B$ virus. Adapted with permission from Robert G. Copyright 1997-2002 http://www.globalserve.net//harlequin/HBV/epidem.htm
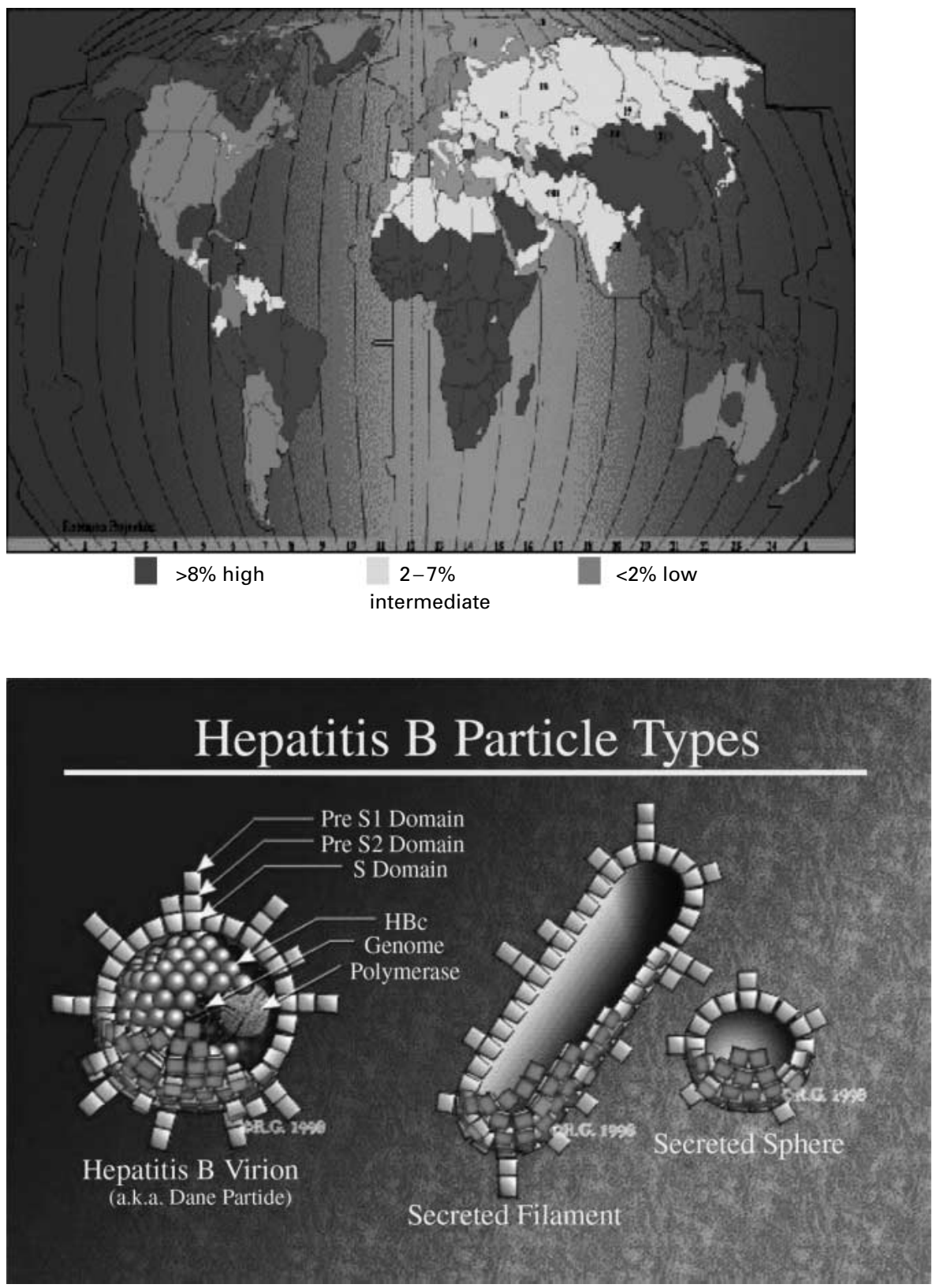

Fig. 2. Hepatitis $B$ virus particle types. Adapted with permission from Robert G. Copyright 1997-2002 http://www.globalserve.net /hharlequin/HBV/hbvparts.htm

\section{Characteristics of the HBV Virus}

The HBV is a small DNA-containing virus belonging to the family Hepadnaviridae [7] (fig. 2). Infected hepatocytes continually secrete viral specific particles that accumulate to high levels (average of 1013/ml) in the blood [7]. These particles are of two types: (1) non-infectious particles consisting of excess viral coat protein (HBsAg) only, and (2) lower amounts (maximum of $10^{10} / \mathrm{ml}$ ) of infectious, DNA-containing particles (Dane particles). The 
Fig. 3. Hepatitis B virus genome. Adapted with permission from Robert G. Copyright 1997-2002 http://www.globalserve.net/hharlequin/HBV/genome.htm

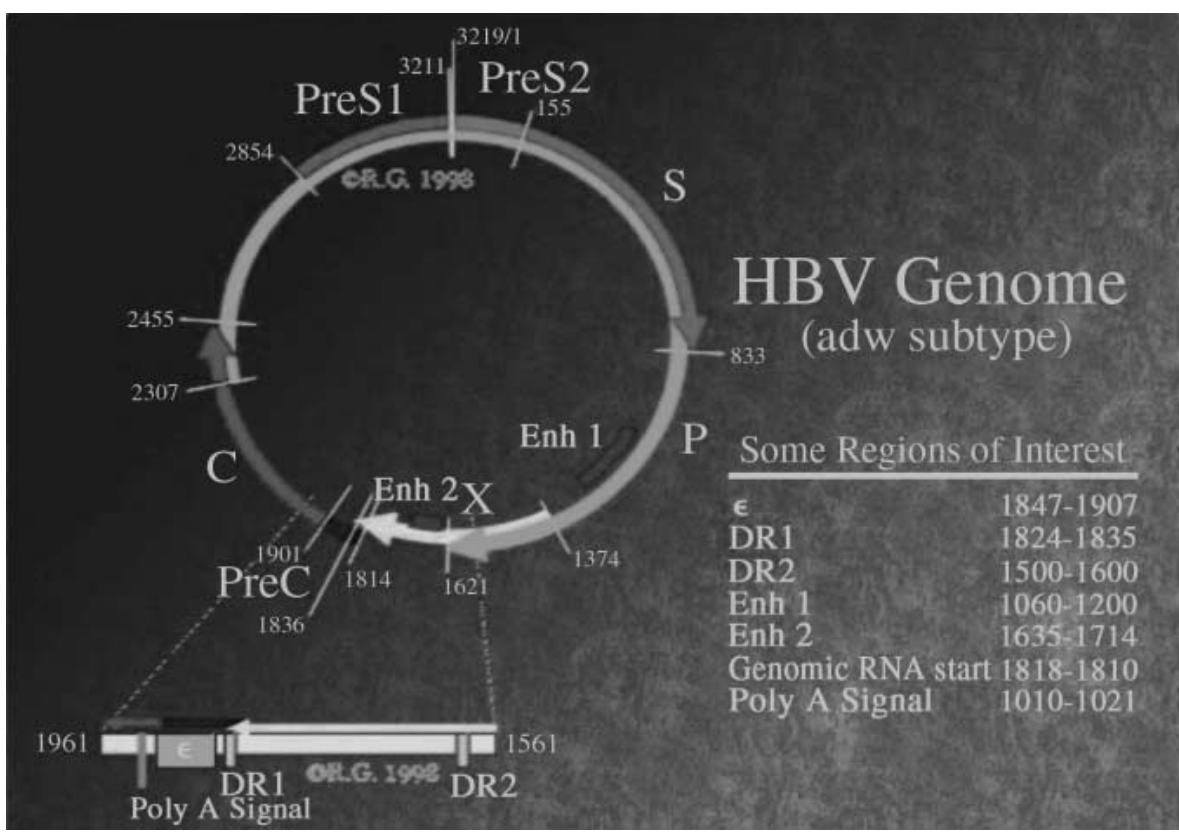

outer envelope, which contains high amounts of HBV surface proteins, surrounds the inner nucleocapsid [8-10]. The nucleocapsid also contains at least one hepatitis B polymerase protein copy as well as the HBV genome (fig. 3) [11].

\section{Epidemiology and Transmission of HBV Infection}

The HBV is globally distributed and estimated to have infected 350 million people worldwide, making it one of the most common human pathogens [12]. The prevalence of $\mathrm{HBV}$ infections is highest in developing countries in Africa, Asia, and the Pacific Islands and lowest in developed countries (table 1). In Africa and Asia where infection is endemic, it is usually acquired in the first decade of life. The way the disease spreads however may differ in these regions [13]. In areas of high HBV incidence, transmission is usually vertical from infected mother to child, or horizontal within families. In intermediate areas of prevalence, HBV is spread horizontally, with the highest rate of infection occurring among older children, adolescents and adults. In areas of low prevalence, HBV is primarily a disease of adolescents and young adults and is transmitted sexually or parenterally [14].

The frequency with which the HBV carrier state develops is markedly influenced by age at initial infection.
Adults with hepatitis usually recover and rarely develop chronic hepatitis or the HBsAg carrier state. In contrast, $\mathrm{HBV}$ infection in neonates and infants usually leads to the chronic carrier state. The percentage of infections resulting in persistent $\mathrm{HBV}$ is dependent on the age at infection: $70-90 \%$ at less than 1 year of age, $40-70 \%$ at around $2-3$ years of age, $10-40 \%$ at 4 and 6 years, and $5-10 \%$ over 7 years [15]. In most population studies, the chronic HBsAg carrier state is 1.5-2 times more frequent in men than in women. Genetic factors may also play a role [16, 17].

The prevalence of $\mathrm{HBV}$ infections in developing regions is not well documented. In Africa it is estimated that approximately $98 \%$ of the 470 million inhabitants are infected with the virus at some time during their lives and about 10\% develop chronic infections [18]. In China and Southeast Asia, vertical transmission is responsible for about $50 \%$ of the chronic carrier rate, but in other areas of high endemicity such as the Middle East and India, horizontal transmission among children and young adults is more important [19].

HBV transmission occurs through exchange of body fluids and blood contact. The mode of spread may be changing in industrialized countries. Transmission of HBV among homosexual males has diminished dramatically in the last decade due to reduction in risky sexual behavior induced by the AIDS epidemic. In the USA, a larger proportion of cases are being observed in intravenous drug abusers ( $28 \%$ of cases) and in active heterosex- 
Table 1. Worldwide distribution of hepatitis B virus infection

\begin{tabular}{llll}
\hline & \multicolumn{2}{l}{ Endemic status } & \\
\cline { 2 - 4 } & low & intermediate & high \\
\hline $\begin{array}{lll}\text { Prevalence } \\
\text { Chronic infection }\end{array}$ & $<2 \%$ & & \\
Total infection & $<20 \%$ & $2-7 \%$ & $8-15 \%$ \\
Distribution & North America & Eastern Europe & $>60 \%$ \\
& Western Europe & Southeast Asia \\
& Australia & Soviet Union & China \\
& New Zealand & Central Asia & Inilippines? \\
& South America & Japan & Middle East \\
& (Southern) & Israel & Africa \\
& & South America & Amazon Basin \\
& & (Northern) & Pacific Islands \\
& & & Arctic (Inuit) \\
\hline
\end{tabular}

uals with multiple partners (24\% of cases) [20]. Immigrants or refugees from areas of high endemicity, as well as travellers and military servicemen in such areas, constitute other important high-risk groups. There is a low rate of vertical transmission of HBV from mother to child, which makes only a small contribution to the pool of infection.

In Africa, the predominant route of infection is horizontal [21]. Familial clustering of HBV infection has been extensively documented in regions such as South Africa [22], although the precise mechanisms of transmission are not known [23, 24]. The first (and largest) wave of HBV infection in black Africans begins during the latter half of the first year of life and high carrier rates are already present by the age of 3-5 years [21, 25-27]. Vertical transmission from mother to child makes only a small contribution to the pool of infection. In the Far East and Mediterranean countries, maternal-infant perinatal transmission is the predominant early route of infection, with vertical transmission being the predominant route of infection [28]. The general pattern of HBV infection however is similar in all these regions.

\section{Pathology of HBV-Associated Glomerulonephritis}

Almost all morphological forms of renal disease including MN, membranoproliferative glomerulonephritis, mesangial proliferative glomerulonephritis, minimal change disease, IgA nephropathy, focal segmental glomerulosclerosis, have been described [29-32]. The major renal manifestations of $\mathrm{HBV}$ are summarized in table 2.
Table 2. Renal manifestation of hepatitis B virus

Membranous nephropathy

Membranoproliferative glomerulonephritis Mesangial proliferative glomerulonephritis IgA nephropathy

Serum-sickness-like syndrome

Polyarteritis nodosa

Lupus nephritis ${ }^{1}$

Crescentic glomerulonephritis ${ }^{1}$

Focal segmental glomerulosclerosis ${ }^{1}$

Minimal change nephrotic syndrome ${ }^{1}$

1 Most likely incidental findings.

\section{Membranous Nephropathy}

Brzosko et al. [53] first described this pathological entity, and subsequent reports from other countries showed that the strongest association of chronic HBV carriage, particularly in children, is with $\mathrm{MN}$ [1, 7, 31, 33-39]. In children, HBV-associated membranous nephropathy (HBVMN) resolves spontaneously in many cases, usually in association with the appearance of free anti-HBeAb in the circulation [40, 41]. However, resolution is relatively uncommon in adults, most of whom appear to have progressive disease over time [42, 43].

\section{Membranoproliferative Glomerulonephritis}

Membranoproliferative glomerulonephritis associated with chronic HBV infection is characterized by the deposition of circulating antigen-antibody complexes in the mesangium and subendothelial space. These glomerular 
deposits consist mainly of $\operatorname{IgG}$ and C3 [44-47]. Both membranoproliferative glomerulonephritis type I and III have been described, but type II (dense deposit disease) has not been reported [42]. HBsAg and HBeAg have been implicated in this disorder, although their exact role remains uncertain [41].

\section{Mesangial Proliferative Glomerulonephritis}

Coexistence of mesangial proliferative glomerulonephritis with predominant mesangial IgA deposits and persistent hepatitis B surface antigenemia was first reported in 5 patients by Nagy et al. [48] and later in 2 patients by Slusarczyk et al. [39]. In IgA nephropathy, glomerular $\mathrm{HBeAg}$ deposits were not found in renal biopsies, but mesangial deposits of $\mathrm{HBsAg}$ similar to the distribution of IgA immunostaining were detected in 40 and $21 \%$ of renal biopsies by polyclonal and monoclonal antibodies, respectively $[48,49]$.

Subsequent studies by Lai et al. [37, 49, 50] also supported the association of chronic HBV infection with mesangial IgA nephropathy. More recently, Bhimma et al. [1] reported $6(26 \%)$ of 23 children with HBV-associated glomerular disease other than $\mathrm{MN}$ to have mesangial proliferative glomerulonephritis. Circulating immune complexes, particularly large circulating immune complexes, are deposited principally in the mesangial regions and subendothelial space [51]. It is unclear whether IgA present in glomeruli has a specific anti-HBs antibody activity or not. Lai et al. [50] demonstrated HBcAg by immunoperoxidase within the nuclei of mesangial cells in patients with HBV-associated IgA nephropathy. The association may be incidental as the prevalence of the HBsAg carrier state among patients with this lesion is much lower compared to those with $\mathrm{MN}$ or membranoproliferative glomerulonephritis.

\section{Polyarteritis nodosa}

The features of HBV-associated polyarteritis nodosa are identical to those of idiopathic polyarteritis nodosa. Polyarteritis typically occurs within 4 months of onset of HBV infection [44]. Circulating antigen-antibody complexes induced by HBV infection are deposited in the vessels $[6,42]$. The renal pathology may be limited to medium-sized arteries with ischemic changes in the glomeruli [56]. However, various forms of glomerulonephritis, including diffuse proliferative [57, 58], mesangial proliferative [57], and membranous [58], may accompany polyarteritis.

\section{Other Histological Associations of $\mathrm{HBV}$}

The association between chronic HBV infection and focal segmental glomerulosclerosis, minimal change nephropathy $[37,52,53]$ and lupus nephritis may be fortuitous $[54,55]$.

\section{Pathogenesis of HBV-Associated Nephropathy}

Epidemiological, clinical and immunological evidence suggest a causal association between HBV carriage and the development of nephropathy $[59,60]$. The pathogenetic mechanisms by which individuals with chronic HBV infection develop nephropathy are not clearly defined, although immunological processes related to immune complex deposition have been implicated [61, 62]. Genetic factors may also play a role [63]. Evidence supports a genetic predilection for the persistence of HBV antigenemia and for protection against HBV infection (see below) [63].

Four major mechanisms could induce renal tissue injury by HBV: (1) By cytopathic effect induced by virus infection of the cell. (2) By tissue deposition of immune complexes of viral antigen and host antibody. (3) By virus-induced specific immunological effector mechanisms (specific T lymphocyte or antibody) which damage the kidney. (4) By indirect effects on renal tissue mediated via virus-induced cytokines or mediators.

\section{Immunopathogenetic Mechanisms}

The most widely accepted mechanism associated with nephropathy is the deposition of immune complexes of viral antigen and host antibody. Experimental studies in animals by Germuth et al. [64] demonstrated that, when an animal was exposed to foreign antigen, nephritis developed depending on the circulation of different proportions of antibodies and antigens. In the absence of antibody, with antigen only in the serum, there was no nephritis. When antigen persisted in the serum with low levels of antibody, chronic nephritis with subepithelial deposits developed; the latter are markers of HBV membranous lesions. Previous studies indicated that the hepatitis B envelope antigen $(\mathrm{HBeAg})$ was the primary antigen related to the subepithelial deposits in patients with HBVMN $[65,66]$.

HBV antigens implicated in glomerular diseases may vary according to the histopathological lesions. In HBVMN glomerular deposition of $\mathrm{HBsAg}[53,38]$, HBcAg [37, 40] and $\mathrm{HBeAg}[67,68]$ have been observed. Lai et al. [51] used $F\left(a b^{\prime}\right)_{2}$ fragments to confirm that 
$\mathrm{HBeAg}$ is the specific component deposited in HBV-associated MN. Takekoshi et al. [41] showed that HBeAg exists in the sera of these children in two different forms, free 'small' $\mathrm{HBeAg}$ and $\mathrm{IgG}$-associated 'large' $\mathrm{HBeAg}$, which was presumed to be an immune complex. They proposed that $\mathrm{HBeAg}$ in association with IgG in both the circulation and kidney tissue supported the view that immune complexes, especially those containing $\mathrm{HBeAg}$, were essential in the pathogenesis of HBVMN. Thus, although multiple $\mathrm{HBV}$ antigens are present in $\mathrm{MN}$, these findings support the view that $\mathrm{HBeAg}$ is the antigen most likely responsible for the immunologic injury in HBVMN.

A recent study by Lin et al. [69] set out to elucidate why only some individuals with HBV infection developed $\mathrm{MN}$. They did this by measuring serum $\mathrm{HBeAg}$ circulating immune complexes during the acute nephrotic phase of HBVMN and in the carrier stage of HBV. They found that the level of circulating immune complexes was low in the HBVMN patients, and absent in $\mathrm{HBsAg}+/ \mathrm{HBeAg}+$ patients without $\mathrm{HBVMN}$, and in $\mathrm{HBsAg}+/ \mathrm{HBeAg}-$ asymptomatic carriers. In addition, they found that HBVMN patients had lower cytotoxic T-cell activity than did $\mathrm{HBV}$ carriers, $\mathrm{HBsAg}-/ \mathrm{HBsAb}+$ subjects and $\mathrm{HBeAg}-/ \mathrm{HBeAb}+$ children, using autologous HBcAg-expressing Epstein-Barr virus-immortalized lymphoblastoid cell lines as stimulator/target cells. From the in vitro cytokine production study of peripheral blood $\mathrm{T}$ cells after stimulation with $\mathrm{HBcAg}$, they found that T-helpercell-1-related interleukin (IL)-2 and IFN- $\gamma$ production were very low in HBVMN patients but T-helper-cell-2related IL-10 production was higher in $\mathrm{HBsAg}+/ \mathrm{HBeAg}+$ patients with HBVMN than in those without HBVMN. Based on these findings, they concluded that HBVMN children seem to have an inadequate cellular immune response to $\mathrm{HBcAg}$.

A study by Xin et al. [70] from China investigated the impact and significance of HBV DNA in the pathogenesis of HBV-associated nephropathy. Renal tissue from 43 children with HBV-associated glomerulonephritis was examined for HBV DNA by in situ hybridization assay. HBV DNA was identified in 41 of the 43 cases $(95.3 \%)$ and was distributed generally in the nucleus and cytoplasm of epithelial cells and mesangial cells of glomeruli, and epithelial cells of renal tubules. HBV DNA also existed simultaneously in renal interstitial tissue in some of the cases. The positive results from HBV DNA in situ hybridization correlated well with HBV antigen assays. The duration of proteinuria in cases with HBV DNA in renal tubules was much longer than in those with no HBV
DNA in renal tubules. The analysis implied that the more extensive the existence of HBV DNA in the nephron unit and interstitial tissue, the more severe the clinical manifestation. Zhou et al. [71] also reported that the existence of HBV DNA usually coincides with the presence of HBV antigens. This implied that HBV antigens, particularly $\mathrm{HBcAg}$ and its immunocomplex, could result from both antigens derived from local expression and arriving from the circulation. The authors concluded that renal persistence of the HBV genome or genes could lead to the expression of viral antigens in this tissue and cause cytopathology and aberrant immune responses.

HBV-associated glomerulonephritis in chronic carriers of HBV may in fact not result from the direct effects of the virus. Nephropathy may be the end result of an underlying immunological abnormality or genetic predisposition that increases the likelihood of these subjects developing HBV carrier state independently of HBVMN [6]. Conditions associated with defective cell-mediated immunity predispose $\mathrm{HBV}$-infected patients to the chronic $\mathrm{HBsAg}$ carrier state [72-74]. Increased production of circulating mediators (such as tumor necrosis factor, interferons, IL-8, and/or other factors) from secondary liver disease in genetically predisposed individuals, may lead to increased glomerular permeability to plasma proteins [6]. Further studies are needed to confirm these hypotheses. Immune complexes containing different combinations of $\mathrm{HBV}$ antigens may be responsible for $\mathrm{HBV}$-associated IgA nephropathy and membranoproliferative glomerulonephritis.

\section{Biosocial Background}

Little is understood of the biosocial context in which HBV-associated nephropathy (particularly $\mathrm{MN}$ ) develops. Bhimma et al. [22] undertook two studies to determine the ecology of HBVMN by evaluating HBV status and proteinuria in family members and household contacts of index children with HBVMN to test the hypothesis that HBV carriage and asymptomatic proteinuria are closely linked and may be causally associated. In a study of 152 family members and 43 household contacts of 31 index cases of black children with biopsy-proven HBVMN, they found strong clustering of HBV in family members, up to $37 \%$ of HBV-infected individuals in multiplex families of index HBVMN cases, compared to $19.9 \%$ in households of children with HBV carriage alone in the same population. Fifty-three (27\%) of the family members and household contacts had a protein:creatinine ratio greater than the physiological limit of 0.2 . The frequency of abnormal proteinuria was not significantly dif- 
ferent in those with $(22(30.5 \%)$ of 72$)$ or without $(33$ (32\%) of 104) HBV carriage. This lack of association remained when carriers were classified into those who were HBsAg positive only and those with active viral replication (HBsAg and/or $\mathrm{HBeAg}$ and/or HBV DNA; $\mathrm{p}=$ 0.07). Although family members were more predisposed to HBV carriage than household contacts, both had an equal frequency of abnormal proteinuria $(p=0.48)$. Age had a significant impact on proteinuria, with children less than 5 years being more likely to have abnormal proteinuria $(\mathrm{p}=0.008)$.

The prevalence of abnormal proteinuria in family members and household contacts of the index cases was more than in community-based controls. Communitybased controls consisted of 123 subjects, none of whom were related to the children with HBVMN. All controls were tested for hepatitis $\mathrm{C}$ virus and were found to be negative for anti-HCV. All were negative for $\mathrm{HBV}$ and HIV-1. None had evidence of any coexisting illnesses. None were screened for parasites. One hundred and five $(85 \%)$ had a protein:creatinine ratio in the normal range. Thirteen (11\%) had mild proteinuria, and $5(4 \%)$ had moderate proteinuria. Children less than 5 years of age in the control group had a higher incidence of abnormal proteinuria (21\%) compared with older children and adults $(12 \%)$, but the differences were not statistically significant $(\mathrm{p}=0.22)$ on $\chi^{2}$ analysis.

There were no differences in the genotype of the virus in the index cases and those found in the households.

\section{Pattern of Proteinuria}

We undertook more detailed analysis of the pattern of proteinuria detected in these household subjects using sodium dodecyl sulfate polyacrylamide gel electrophoresis (SDS-PAGE). IgG and haptoglobulin on SDS-PAGE were suggestive of MN [75]. Seventy-two (37\%) of the 195 family members and household contacts were HBV carriers; 21 (29\%) of these carriers had evidence of proteinuria on SDS-PAGE. Twenty-eight (41\%) of the 68 members of the study group who were HBV negative and 27\% of the controls also showed proteinuria on SDS-PAGE. This lack of association between HBV carriage and proteinuria remained when controlled for sex and family relationship. Those having a pattern of proteinuria suggestive of MN were more likely to have an abnormal protein:creatinine ratio $(\mathrm{p}=0.001)$.

The lack of association between HBV carriage and abnormal proteinuria (protein:creatinine ratio $>0.2$ or IgG and haptoglobulin on SDS-PAGE) led the authors to the conclusion that $\mathrm{HBV}$ alone is not sufficient for the development of HBVMN. It was postulated that in HBV carriers, additional interactions between socio-environmental conditions and possible genetic factors in specifically vulnerable individuals, might be responsible for the development of HBVMN.

\section{Genetic Factors}

In order to determine the genetic basis for the development of MN, the authors investigated 30 black children with biopsy-proven HBVMN. HLA class I and II antigen frequencies of the study subjects, when compared to controls that were healthy blood donors from the same population, showed a significantly increased frequency of HLA DQB1*0603 in patients with HBVMN compared to controls $\left(\chi^{2}=13.65\right.$, $p$ value corrected for the number of antigens detected $(P c)<0.001$; RR 4.3). DRB1*07 and DQB $1 * 02$ were increased in frequency in the study subjects but failed to reach statistical significance. There was no significant difference in the frequencies of class 1 antigens in the study group compared to controls. Based on the significant frequency of class II antigens (HLA DQB1*0603), a possible genetic predisposition to the development of HBVMN was proposed [76].

Fourteen children with HBVMN from the above cohort positive for HLA DQB $1 * 0603$ had 70 of their family members studied to test for an association between this gene, HBV carriage and the development of abnormal proteinuria using the mean probability ratio (lod scores). There was a lack of association between HLA DQB1*0603 with either HBV carriage or abnormal proteinuria in family members, suggesting that other factors may play a role in predisposing children to these two disorders. It would appear that the main effect of HLA DQB1*0603, which distinguishes HBVMN from family members, is the degree of proteinuria which is a reflection of the severity of glomerular basement membrane damage [77].

Another study by Vaughan et al. [78] reported on HLA-DRB and DQB1 alleles in 42 children with HBVMN. The frequency of these alleles was compared to 55 healthy age-matched children and 40 patients chronically infected with HBV without any renal involvement, as HBV controls. The hypothesis framed in this study was that, as idiopathic $\mathrm{MN}$ and low responsiveness to $\mathrm{HBV}$ vaccine have been found to be associated with DR3 in Caucasians, it was likely that patients with HBVMN would show an increase in DR3. The results of the study showed that although there was a small increase in the frequency of DRB $1 * 0301$ in the HBVMN patients (16/ $42,38 \%)$ when compared to healthy controls $(15 / 55$, 
Fig. 4. Hypothesis for the pathogenetic mechanisms in the development of hepatitis $B$ virus-associated membranous nephropathy.

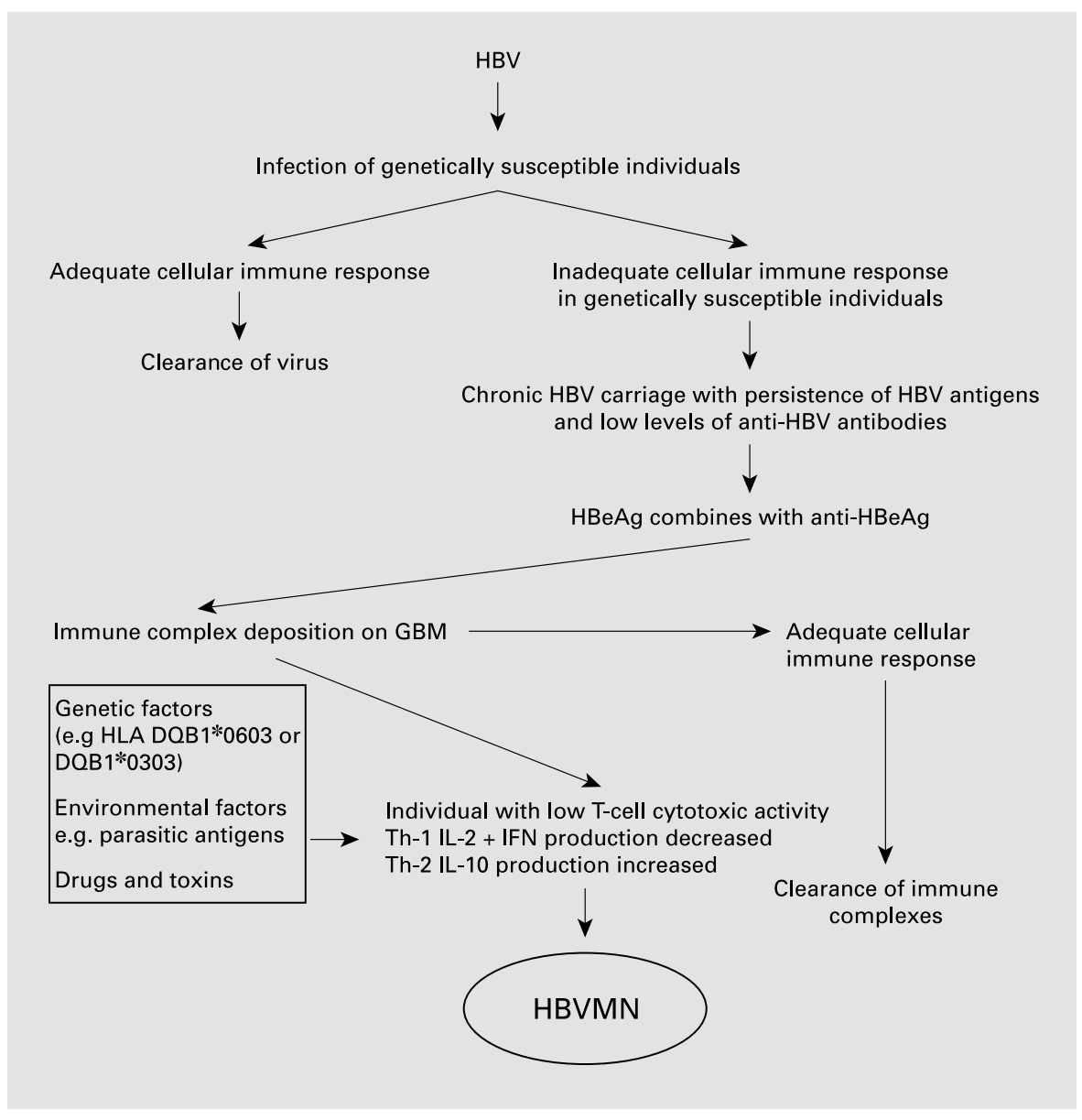

$31 \%$ ), this difference did not reach statistical significance $\left(\chi^{2}=0.83, p=0.36\right)$. There was a significant increase in the frequency of DQB $1 * 0303$ in the HBVMN patients vs. the healthy controls $(13 / 42$ vs. $2 / 55, \mathrm{RR}=11.6, P c=$ $\left.0.007, \mathrm{p}_{\mathrm{c}}=0.02\right)$. A similar increase in DQB $1 * 0603$ was seen in the HBVMN patients when compared to the HBV control subjects (13/42 vs. $4 / 40)$, but this was only significant before correction $(\mathrm{RR}=4.3, \mathrm{p}=0.04)$. The authors postulated that in Caucasians DQB $1 * 0603$ may be associated with poor clearance of $\mathrm{HBeAg}$, leading to $\mathrm{HBeAg}$ deposition on the epithelial side of the glomerular basement membrane and subsequent development of MN.

Taken together, it would appear that that the pathogenetic mechanism by which individuals develop nephropathy are probably dependent on interactions between viral, host and environmental factors. Thus a chronic HBV infection in itself is not sufficient for the development of nephropathy (particularly MN), but requires interplay of genetic and environmental factors in specifically vulnerable individuals to lead to the development of nephropa- thy. Viral characteristics do not appear to play a major role in the development of nephropathy, but further studies are needed to determine the role of viral genotype in the development of MN (fig. 4).

\section{Clinical Presentation of HBVMN}

The clinical manifestations of HBVMN in pediatric and adults patients tend to be different (table 3). Pediatric chronic HBV carriers are not infrequently asymptomatic and HBV-associated nephropathy is detected by routine urine and serological screening [37, 52, 79]. The other common clinical presentation in children is the nephrotic syndrome. There is a strong male predominance $[38,52$, $67,68]$. In adults, proteinuria and the nephrotic syndrome are most common manifestations. The male predominance of the nephritis in the adult population is less prominent than that in children $[52,77,80]$. Adults with HBVMN from non-endemic areas are more likely than 
Table 3. HBV-associated nephropathy differences in clinical presentation between children and adults

\begin{tabular}{|c|c|}
\hline Children & Adults \\
\hline $\begin{array}{l}\text { Mode of transmission } \\
\text { Vertical transmission in the Far East } \\
\text { Horizontal transmission in USA, Africa and Europe }\end{array}$ & $\begin{array}{l}\text { Often unknown } \\
\text { Horizontal transmission in areas of high endemicity; } \\
\text { in areas of low endemicity often associated with } \\
\text { drug abuse or sexual transmission }\end{array}$ \\
\hline $\begin{array}{l}\text { Clinical presentation } \\
\text { Asymptomatic - detected by routine urine and } \\
\quad \text { serological screening } \\
\text { Nephrotic syndrome }\end{array}$ & Nephrotic syndrome and proteinuria \\
\hline $\begin{array}{l}\text { Gender } \\
\text { Strong male dominance }(>80 \%)\end{array}$ & Less pronounced male dominance \\
\hline $\begin{array}{l}\text { Mean age of presentation } \\
\text { Horizontal transmission: } 5-7 \text { years } \\
\text { Vertical transmission: Infancy }\end{array}$ & Any age group \\
\hline $\begin{array}{l}\text { Acute hepatitis } \\
\text { Low incidence }\end{array}$ & $\begin{array}{l}\text { Often present in adults from non-endemic areas where } \\
\text { HBVMN associated with intravenous drug abuse, } \\
\text { homosexuality and acquired immune deficiency } \\
\text { syndrome }\end{array}$ \\
\hline $\begin{array}{l}\text { Histology } \\
\text { Membranous (>85\%) }\end{array}$ & $\begin{array}{l}\text { Usually membranous } \\
\text { Often associated with IgA nephropathy }\end{array}$ \\
\hline $\begin{array}{l}\text { Renal function } \\
\text { Preservation of renal function in over } 95 \% \text { of children }\end{array}$ & Progression to renal failure in $25 \%$ \\
\hline
\end{tabular}

children to have a history of acute hepatitis which could be related to intravenous drug abuse [81], homosexuality [82], and acquired immune deficiency [83].

\section{Clinical Course and Prognosis}

The natural history of HBVMN is incompletely understood. Spontaneous regression of the nephrotic syndrome was reported in $30-60 \%$ of cases of HBVMN, and these patients had usually remained symptomatic for 12 months or longer $[37,38,68,84]$. The remaining patients had persistent proteinuria with fluid retention [37, 38, 84]. Seroconversion to anti-HBeAg is associated with remission of proteinuria $[68,70]$. There have also been reports of progression to renal insufficiency in those patients who do no clear the virus $[37,38,85]$. The majority of children however have a benign course. A report by Gilbert and Wiggelinkhuizen [31] in 1994 in a study from Cape Town reported 71 children with HBV-associated nephropathy. In this cohort of patients, 37 (52.1\%) of patients went into spontaneous remission, this was associated with $\mathrm{HBeAg}$ clearance in 33 patients (89.2\%) over 90 months; the average time of clearance of $\mathrm{HBeAg}$ to remission was 5 months. A second report by Bhimma et al. [1] of 93 children with HBV-associated nephropathy in black children in KwaZulu/Natal in South Africa showed 70 of the 93 patients to have $\mathrm{MN}$ with a pattern of disease similar to that reported from other regions in South Africa.

\section{Worldwide Perspective of HBV-Associated Nephropathy}

The reported prevalence of HBV-associated nephropathy, particularly $\mathrm{MN}$, closely parallels the geographic patterns of prevalence of HBV (fig. 3). In children with HBVassociated nephropathy, it would appear that horizontal transmission of $\mathrm{HBV}$ is the predominant mode of transmission in most regions $[65,86]$. The rarity of HBV-asso- 
ciated nephropathy in developed countries such as the USA and Europe probably reflects the rarity of HBV infection, particularly in children. In the USA, HBVMN is most frequently seen in African Americans [87]. In developed countries, HBV-associated nephropathy is frequently seen in adults who are high-risk groups such as intravenous drug abusers, dialysis patients, etc.

Following the report by Levy and Chen [13] on the worldwide perspective of HBV-associated glomerulonephritis in the 1980s, further reports of HBV-associated nephropathy have been from the southern African continent $[1,31]$. The possible reason for the low reporting of cases of HBV-associated nephropathy is the introduction of HBV immunization in several regions endemic for $\mathrm{HBV}$ infection; the decline in the incidence of HBV-associated nephropathy accompanying the decline in HBV infection.

\section{Treatment of HBVMN}

Attempts have been made to treat HBVMN for the following reasons: (a) Spontaneous remission does not necessarily occur in all nephrotic patients and $40-70 \%$ of patients continue to have proteinuria (with or without symptoms). Complications related to overt nephrotic syndrome such as hyperlipidemia, edema, and venous thrombosis have been observed in these patients. (b) There is improvement of the liver disease and renal involvement following clearance of $\mathrm{HBsAg}$ from the blood [50]. (c) The disease may progress in a small percentage of patients and result in chronic renal insufficiency $[38,85]$.

\section{Corticosteroids}

Corticosteroid therapy used in primary $\mathrm{MN}$ has been administered to some patient with HBV-associated nephropathy as a therapeutic trial for symptomatic relief of proteinuria $[80,88]$. However, corticosteroids given at the onset of nephrotic syndrome in HBVMN do not seem to have an ameliorative effect on the nephrotic state or lead to clearance of the virus [89].

Exacerbation of liver impairment following abrupt withdrawal of corticosteroids has been reported in patients with chronic HBV hepatitis [90]. In contrast to patients with chronic active hepatitis, patients with HBVassociated MN may not have evidence of hepatic dysfunction and their liver biopsies may even be normal [37,38]. A prospective trial (compared with historic controls) of corticosteroids in nephrotic patients with HBVMN was conducted by Lai et al. [80]. In this study, 8 patients with HBVMN were treated with corticosteroids for 6 months and compared to 7 similar patients previously treated with diuretics alone who acted as historical controls. Corticosteroid therapy induced transient viral replication with increased serum concentration of hepatitis B virus e antigen and hepatitis B virus DNA. Two of the 7 patients receiving diuretics developed spontaneous remission though apparently later than those receiving corticosteroid. Histopathological examination of post-treatment renal biopsy in a single patient revealed histological progression, which did not support a protective value of corticosteroid therapy [91]. Furthermore, the appearance of virus-like particles in the glomeruli after corticosteroid therapy supported the serological evidence of active viral replication. Hence, these studies do not support use of corticosteroids in HBV-associated nephropathy.

\section{Alternative Therapies}

A priority of HBV research is the development of safe and effective anti-viral therapies. $\alpha$-Interferon on (IFN- $\alpha$ ), a naturally occurring cytokine is produced by B-lymphocytes, null lymphocytes, and macrophages [92-94]. IFN- $\alpha$ has anti-viral, anti-proliferative and immunomodulatory effects [95]. In 1993, a meta-analysis of all studies in patients with chronic HBV carriage showed IFN- $\alpha$ therapy was beneficial in HBeAg-positive patients who were treated for 3-6 months [96]. Treated patients were much more likely than controls to seroconvert to anti-HBe and to show normalization of liver enzymes (alanine aminotransferase) [96].

There has been only one report of a randomized, controlled trial of IFN- $\alpha$ in Chinese children with HBV-associated nephropathy; other studies have been mainly in small numbers of adult patients [46, 47, 95, 97]. In the only open, randomized trial conducted by Lin [97] in Taiwan in $40 \mathrm{HBVMN}$ patients who showed no response to corticosteroid treatment, 20 patients were treated with IFN- $\alpha$ and 20 were given supportive treatment only. $\mathrm{HBeAg}$ and HBsAg were positive in all patients. At the end of 3 months of treatment, all patients treated with IFN- $\alpha$ were free of proteinuria. In contrast, 10 patients $(50 \%)$ had nephrotic range proteinuria and 10 patients $(50 \%)$ had mild proteinuria with exacerbation during respiratory tract infection. At the end of the 12th month, 8 patients in the group treated with only supportive therapy had nephrotic range proteinuria and 12 patients (40\%) had mild proteinuria with frequent relapses. In the group treated with IFN- $\alpha, 8$ patients (40\%) had HBeAg seroconversion between the 4th and 6th months and HBsAg sero- 
conversion between the 10th and 12 th months. HBe seroconversion only [HBeAg-/HBsAg+] was found in 4 patients. Four patients had no change in HBV serological markers [HBeAg+/HBsAg+]. The remaining 4 patients had $\mathrm{HBeAg}-/ \mathrm{HBeAb}+\mathrm{HBsAg}-/ \mathrm{HBsAb}-$ at the end of the 12 th month. In contrast, there was no seroconversion of $\mathrm{HBeAg}+/ \mathrm{HBsAg}+$ in those treated conservatively. There have been no similar reports from sub-Saharan Africa, where most countries are hyperendemic for HBV infection. In most controlled studies, performed in Caucasian children, IFN therapy achieved clearance of HBV-DNA and $\mathrm{HBeAg}$ in $30-50 \%$ of treated patients. In the only study of black children with HBV-associated nephropathy from Africa, 24 patients were treated with interferon- $\alpha 2 b$ (Intron $A^{\circledR}$ ) as part of an open-labelled, clinical, observational study during the period April 1997 to June 1999. Ten of the children who completed 16 weeks of therapy responded with clearance of $\mathrm{HBeAg}$ by 40 weeks. None cleared HBsAg. All responders showed remission of proteinuria, 8 maintained renal function and 2 showed improvement of renal function. HBV DNA levels decreased in those that responded. Nine patients did not clear $\mathrm{HBeAg}$; none showed remission of proteinuria, 2 had a decline in renal function. Five patients defaulted treatment. Liver enzymes rose during treatment in all patients that were treated but declined subsequently, irrespective of the response to therapy. No serious side effects were encountered [98].

The mechanism by which IFN- $\alpha$ results in clearance of HBV antigens has not been fully elucidated, but it is believed that the interaction of IFN- $\alpha$ with the cytokine cascade and T-cell system is pivotal to its mechanism of action. IFN- $\alpha$ has been shown to induce the proliferation of natural killer cells, which are helpful in clearing the virally infected cells [92-94]. Stimulation by IFN- $\alpha$ results in proliferation of cytotoxic CD8+ T cells [92-94] and induces the differentiation of T-helper (Th) lymphocytes to Th1helper cells. Th1 lymphocyte stimulation results in the production of proinflammatory cytokines, including IL-2 and IFN- $\gamma$. The latter induces the expression of major histocompatibility complexes antigens I and II on cells. It is postulated that IFN- $\gamma$, tumor necrosis factor- $\alpha$ and IL- $1 \beta$ may cause the evolution of immune-mediated glomerular disease by increased expression of major histocompatibility I antigens of mesangial cells [99].

Clearly more effective therapies for chronic HBV infection in children need to be defined by well-designed randomized controlled studies. Candidate drugs to date include lamivudine, famcyclovir, pegylated interferon, lobucavir, and adepovir.
Table 4. Impact of HBV vaccination on the incidence of HBVMN: average annual incidence rates of HBVMN per $10^{5}$ of the population aged 0-14 years in KwaZulu/Natal, South Africa

\begin{tabular}{llll}
\hline Year & Population & $\begin{array}{l}\text { Cases of } \\
\text { HBVMN }\end{array}$ & $\begin{array}{l}\text { Incidence } \\
\text { rate/105 }\end{array}$ \\
\hline $1984-1985$ & $2,125.527$ & 14 & 0.33 \\
$1986-1987$ & $2,254.972$ & 11 & 0.25 \\
$1988-1989$ & $2,392.300$ & 11 & 0.23 \\
$1990-1991$ & $2,537.991$ & 15 & 0.30 \\
$1992-1993$ & $2,692.554$ & 12 & 0.23 \\
$1994-1995^{1}$ & $2,856.531$ & 12 & 0.21 \\
$1996-1997$ & $3,030.494$ & 26 & 0.43 \\
$1998-1999$ & $3,215.051$ & 16 & 0.25 \\
$2000-2001^{2}$ & $3,360.441$ & 2 & 0.03 \\
\hline
\end{tabular}

1 HBV vaccine introduced; given in 3 doses at 6,10 and 14 weeks after birth. Average vaccine coverage rates for $1 \mathrm{st}, 2 \mathrm{nd}$ and $3 \mathrm{rd}$ doses $85.4,72.2,62.0 \%$, respectively.

2 In comparison with 1994-1995, RR 0.12 (95\% CI 0.03-0.5); $\mathrm{p}=0.003$.

\section{Prevention Strategies}

Immunization, together with screening and appropriate treatment of HBV infection, is important in HBV infection control programmes. This has the potential to eradicate HBV infections and reduce the incidence of HBV-related diseases.

Although in developed regions of the world, where the incidence of HBV infections is very low, the concept of high-risk groups such as dialysis patients, homosexuals, etc. can be defined for the purposes of immunoprophylaxis, this is limited relevance to areas that are endemic for HBV infection. In these regions, all children should be regarded as being at high risk, as most infections are acquired in early childhood.

Several reports of the impact of mass immunization with HBV vaccination [100-112] have documented a significant reduction in the prevalence of $\mathrm{HBsAg}$ carriage and an accompanying decline in the annual incidence of hepatocellular carcinoma. After the introduction of immunization against HBV in July 1984 in Taiwan, an area of hyperendemic prevalence of $\mathrm{HBV}$ infection, HBV carriage in 6-year-old children declined from about $10 \%$ in the period 1981-1986 to between 0.9 and $0.8 \%$ in the period 1990-1994 [112]. Vaccination targets were progressively extended from newborns of HBsAg-positive mothers to all newborns in July 1986 [113], and in 1987 to preschool children as well [114]. 
In a study conducted in Durban, South Africa, HBVMN was used as an endpoint to assess the medium to long-term efficacy of HBV immunization. One hundred and nineteen children, age 1-14 (mean 7) years, with HBVMN comprised the subjects of this study for the period 1984-2001; 101 (85\%) were males. The average annual incidence of HBVMN (calculated as half the incidence over 2 years) during the study period was 0.25 per $10^{5}$ children (range 0.03-0.33) (table 4). The HBV vaccine was introduced in 1995. The average annual incidences in the immediate post-immunization period, as expected, showed no significant decline: these were 0.43 per $10^{5}$ for $1996-1998$ and 0.25 per $10^{5}$ for $1998-1999$ $(\mathrm{p}=0.14$; RR 1.3 (95\% CI 0.9-1.9)). When the average annual rate ratio of HBVMN for the pre-immunization period 1984-1995 (0.22) was compared to the 5-year post-immunization period, 2000-2001 (0.03), there is a sharp decline per $10^{5}$ child population $(\mathrm{p}=0.003$; $\mathrm{RR}=$
$0.12(95 \%$ CI $0.03-0.5))$. HBV vaccine coverage rates during this period were $85.4,78.2$ and $62.0 \%$ for the first, second and third doses, respectively, in children aged 12 23 months [115].

The results of this study indicate that HBV vaccine given as part of routine immunization, even with low coverage rates, is highly effective within the framework of childhood immunization programmes in reducing the incidence of HBVMN.

\section{Acknowledgements}

This work was supported by grants from the Medical Research Council of South Africa and the National Kidney Foundation of South Africa. We thank Dr. Craig B. Langman from the Children's Memorial Hospital in Chicago for editing the manuscript and Mrs. $\mathrm{K}$. Asharam for her assistance in preparation of the manuscript.

\section{References}

1 Bhimma R, Coovadia HM, Adhikari M: Hepatitis B virus-associated nephropathy in black South African children. Pediatr Nephrol 1998; 12:479-484.

2 Combes B, Stastny P, Shorey J, Eigenbrodt EH, Barrera A, Hull AR, Carter NW: Glomerulonephritis with deposition of Australia antigenantibody complexes in glomerular basement membrane. Lancet 1971;ii:234-237.

3 Gocke DJ, Hsu K, Morgan C, Bombardien S, Locksmith M, Christian CL: Association between polyarteritis and Australia antigen. Lancet 1970;ii:1149-1156.

4 Levy Y, Gorevic PD, Kassab HJ, ZuckerFranklin D, Franklin EC: Association between hepatitis B virus and essential mixed cyroglobulinemia. N Engl J Med 1977;296:1501-1508.

5 Takekoshi Y, Tanaka M, Miyakawa Y, Yoshizawa H, Takahashi K, Mayumi M: Free 'small' and IgG-associated 'large' hepatitis B e antigen in the serum and glomerular capillary walls of two patients with membranous glomerulonephritis. N Engl J Med 1979;300:814-819.

6 Johnson RJ, Couser WG: Hepatitis B infection and renal disease: Clinical, immunopathogenetic and therapeutic considerations. Kidney Int 1990;37:663-676.

7 Norder H, Courouce AM, Magnius LO: Complete genomes, phylogenetic relatedness and structural proteins of six strains of the hepatitis $B$ virus, four of which represent two new genotypes. Virology 1994;198:489-603.

8 Crowther RA, Kiselev NA, Bottcher B, Berriman JA, Borisova GP, Ose V, Pumpens P: Three-dimensional structure of hepatitis B virus core particles determined by electron cryomicroscopy. Cell 1994;77:943-950.
9 Nassal H, Schaller H: Hepatitis B virus nucleocapsid assembly; in Doerfer W, Bohm P (eds): Virus Strategies. Weinheim, VCH, 1993, pp 41-75.

10 Onodera S, Ohon $\mathrm{H}$, Yamaki M, Ishida N: Electron microscopy of human hepatitis B virus cores by negative staining - carbon film technique. J Med Virol 1992;10:147-155.

11 Gerlich WH, Robinson WS: Hepatitis B virus contains protein attached to $5^{\prime}$ terminus of its complete DNA strand. Cell 1980;21:801-809.

12 Marshall E: A shadow falls on hepatitis B vaccination effort. Science 1998;281:630-631.

13 Levy M, Chen N: Worldwide perspective of hepatitis B-associated glomerulonephritis in the 80s. Kidney Int 1991;40(suppl 35):24-33.

14 Perrillo RP: Hepatitis B: Transmission and natural history. Gut 1993;(suppl):48-49.

15 Maynard JE, Kane MA, Alter MJ, Hadler SC: Control of hepatitis B by immunization; in Zuckerman AJ, Alan R (eds): Viral Hepatitis and Liver Disease. New York, Liss, 1988, pp 967-973.

16 Yang PM, Sung JL, Chen DS: HLA-A, B, C and DR antigens in chronic hepatitis B viral infection. Hepatogastroenterology 1989;36:363-366.

17 Alper CA, Kruskall MS, Marcus-Bagley D, Craven DE, Katz AJ, Brink SG, Dienstag JL, Awdeh Z, Yunis EJ: Genetic prediction of nonresponse to hepatitis B vaccine. N Engl J Med 1984;321:708-712.

18 Kew MC: Chronic hepatitis B virus infection and hepatocellular carcinoma in Africa. S Afr $\mathbf{J}$ Sci 1992;88:524-528.

19 Nishioka K: Predominant mode of transmission of hepatitis B virus: Perinatal transmission in Asia; in Vyas GN, Dienstag JL, Hoofnagle JH: Viral Hepatitis and Liver Disease. Orlando, Grune \& Stratton, 1984, pp 423-435.
20 Alter M, Hadler SC, Margolis HS, Alexander WJ, Hu PY, Judson FN, Mares A, Miller JK, Moyer LA: The changing epidemiology of hepatitis B in the United States. JAMA 1990;263: 1218-1222.

21 Kew MC: Progress towards the comprehensive control of hepatitis B in Africa: A view from South Africa. Gut 1996;38(suppl 2):31-36.

22 Abdool Karim SS, Thejpal R, Coovadia HM: Household clustering and intra-household transmission patterns of hepatitis B virus infection in South Africa. Int J Epidemiol 1991;20: 495-503.

23 Botha JF, Ritchie MJJ, Dusheiko GM, Mouton HWK, Kew MC: Hepatitis B virus carrier state in black children in Ovamboland: Role of perinatal and horizontal infection. Lancet 1984;ii: 1210-1212.

24 Abdool Karim SS, Coovadia HM, Windsor IM, Thejpal R, van den Ende J, Fouche A: The prevalence and transmission of hepatitis $\mathrm{B}$ virus infection in urban, rural and institutionalised black children of Natal/KwaZulu, South Africa. Int J Epidemiol 1988;17:168-173.

25 Prozesky OW, Szmuness W, Stevens CE, Kew MC, Harley EJ, Hoyland JA, Scholtz JE, Mitchell AD, Shabangu A, Kunene E: Baseline epidemiological studies for a hepatitis B vaccine trial in KaNgwane. S Afr Med J 1983;64: 891-893.

26 Whittle HC, Bradley HK, McLauchan K, Adjukiewicz AB, Howard CR, Zuckerman AJ, McGregor IA: Hepatitis B virus infection in two Gambian villages. Lancet 1983;i:12031206 . 
27 Barin F, Perrin J, Chotard J, Denis F, N'Doye R, Diop Mat I, Chiron JP, Coursaget P, Goudeau A, Maupas P: Cross-sectional and longitudinal epidemiology of hepatitis B in Senegal. Prog Med Virol 1981;27:148-162.

28 Murray-Lyon IM: Strategies for preventing hepatitis B. Quart J Med 1989;264:227-228.

29 Ching-Yuang L: Clinical features and natural course of HBV-related glomerulopathy in children. Kidney Int 1991;40(suppl 35):46-53.

30 Coovadia HM, Adhikari M, Moodley M: Hepatitis B 's' and 'e' antigen carriage in childhood nephrotic syndrome predicts membranous glomerulonephritis. Ann Trop Paediatr 1993;13: 79-82.

31 Gilbert RD, Wiggelinkhuizen J: The clinical course of hepatitis B virus-associated nephropathy. Pediatr Nephrol 1994;8:11-14.

32 Seggie J, Nathoo K, Davies PG: Association of hepatitis $\mathrm{B}(\mathrm{HB})$ antigenaemia and membranous glomerulonephritis in Zimbabwean children. Nephron 1984;38:115-119.

33 Adhikari M, Coovadia HM, Chrystal V: Extramembranous nephropathy in black South African children. Ann Trop Paediatr 1983;3:1724.

34 Coovadia HM, Adhikari M, Morel-Maroger L: Clinico-pathological features of the nephrotic syndrome in South Africa. Q J Med 1979;48: 77-91.

35 Wong V, Ip H, Reesink H, Lelie PN, ReerinkBrongers EE, Yeung CY, Ma HK: Prevention of the HBsAg carrier state in newborn infants of mothers who are chronic carriers of $\mathrm{HBsAg}$ and $\mathrm{HBeAg}$ by administration of hepatitis $\mathrm{B}$ vaccine and hepatitis B immunoglobulin. Lancet 1984;i:921-926.

36 Takeoshi Y, Tanaka M, Shida N, Satake Y, Saheki Y, Matsumoto S: Strong association between membranous nephropathy and hepatitis-B surface antigenaemia in Japanese children. Lancet 1978;ii:1065-1068.

37 Lai KN, Lai FM, Chan KW, Chow CB, Tong $\mathrm{KL}$, Vallance-Owen J: The clinico-pathological features of hepatitis B virus associated glomerulonephritis. Q J Med 1987;63:323-333.

38 Hsu HC, Lin GH, Chang MH, Chen CH: Association of hepatitis $\mathrm{B}$ surface antigenaemia and membranous nephropathy in children in Taiwan. Clin Nephrol 1983;20:121-129.

39 Slusarczyk J, Michalark T, Nazarewick De Mezer T, Krawczynski K, Nowoslawski A: Membranous glomerulonephritis associated hepatitis B core antigen immune complexes. Am J Pathol 1980;98:29-39.

40 Knecht GI, Chrisari FV: Reversibility of hepatitis B virus-induced glomerulonephritis and chronic active hepatitis after spontaneous clearance of serum hepatitis B surface antigen. Gastroenterology 1978;75:1152-1154.

41 Takekoshi Y, Tochimaru H, Nagata Y, Itami $\mathrm{N}$ : Immunopathogenetic mechanisms of hepatitis B virus-related glomerulopathy. Kidney Int 1991;40(suppl 35):34-39.

42 Lai KN, Lai FM: Clinical features and natural history of hepatitis B virus-related glomerulopathy in adults. Kidney Int 1991;25(suppl):4045.
43 Lai KN, Li PK, Lui SF, Au TC, Tam JS, Tong KL, Lai FM: Membranous nephropathy related to hepatitis B virus in adults. N Engl J Med 1991;324:1457-1463.

44 Guillevin L, Lhote H, Cohen P, et al: Polyarteritis nodosa related hepatitis B virus. A prospective study with long-term observation of 41 patients. Medicine (Baltimore) 1998;74:238.

45 Lisker-Melman M, Webb D, Di Bisceglie, A, Kassianides C, Martin P, Rustgi V, Waggoner JG, Park J, Hoofnagle JH: Glomerulonephritis caused by chronic hepatitis B virus infection: Treatment with recombinant $\alpha$-interferon. Ann Intern Med 1989;111:479-483.

46 Conjeevaram HS, Hoofnagle JH, Austin HA, Park Y, Fried MW, Di Bisceglie AM: Longterm outcome of hepatitis B virus-related glomerulonephritis after therapy with interferona. Gastroenterology 1995;109:540-546.

47 Abbas NA, Pitt MA, Green AT, Solomon LR: Successful treatment with hepatitis B virusassociated membranoproliferative glomerulonephritis with $\alpha$-interferon. Nephrol Dial Transplant 1999;14:1272-1275.

48 Nagy J, Bajtai G, Brasch H, Sule T, Ambrus M, Deak G, Hamori A: The role of hepatitis N surface antigen in the pathogenesis of glomerulonephritis. Clin Nephrol 1979;12:109-116.

49 Lai KN, Lai FM, Lo S, Lam CW: IgA nephropathy associated with hepatitis B virus antigenemia. Nephron 1987;47:341-343.

50 Lai KN, Lai FM, Tam JS: IgA nephropathy associated with chronic hepatitis B virus infection in adults. J Pathol 1989;157:321-327.

51 Lai KN, Lai FM, Tam JS: Comparison of polyclonal and monoclonal antibodies in determination of glomerular deposits of hepatitis B virus antigens in hepatitis B virus-associated glomerulonephritis. Am J Clin Pathol 1989;92: 159-165.

52 Lai KN, Lai FM, Tam JS, et al: High prevalence of hepatitis B surface antigenaemia in nephrotic syndrome in Hong Kong. Ann Trop Paediatr 1989;9:45-48.

53 Brzosko WJ, Krawczynski K, Nazarewicz T, Morzycka M, Nowoslowski A: Glomerulonephritis associated with hepatitis B surface antigen immune complexes in children. Lancet 1974;ii:476-482.

54 Looi LM, Prathap K: Hepatitis B virus surface antigen in glomerular immune complex deposits of patients with systemic lupus erythematosus. Histopathology 1982;6:141-147.

55 Lai KN, Lai FM, Leung A, Lo S: Is that a pathogenetic role of hepatitis B virus in lupus nephritis? Arch Pathol Lab Med 1987;111:185-188.

56 Gerber MA, Brodin A, Steinberg D, Vernace Y, Yang CP, Paronetto F: Periarteritis nodosa, Australia antigen and lymphatic leukaemia. N Engl J Med 1972;286:14-17.

57 Duffy J, Lidsky MD, Sharp JT, Davis JS, Person DA, Hollinger FB, Min KW: Polyarthritis, polyarteritis and hepatitis B. Medicine 1976; 55:19-37.

58 Michalak T: Immune complexes of hepatitis B surface antigen in the pathogenesis of periarteritis nodosa. A study of seven necropsy cases. Am J Pathol 1978;90:619-632.
59 Vehaskari VM, Robson AM: Proteinuria; in Eldelmann CM Jr, Bernstein J, Meadow SR, Spitzer A, Travis LB (eds): Pediatric Kidney Diseases, ed 2. Boston, Little Brown, 1992, pp 531-551.

60 Lai KN, Ho RTH, Tam JS, Lai FMM: Detection of hepatitis B virus DNA and RNA in kidneys of HBV-related glomerulonephritis. Kidney Int 1996;50:1965-1977.

61 Couser WG, Salant DJ: In situ immune complex formation and glomerular injury. Kidney Int 1980;17:1-13.

62 Couser WG, Abrass CK: Pathogenesis of membranous nephropathy. Ann Res Med 1988;39: 517-530.

63 Thursz MR, Kwiatkowski D, Allsopp CEM, Greenwood BM, Thomas HC, Hill AVS: Association between the MHC class II allele and clearance of hepatitis virus in the Gambia. N Engl J Med 1995;332:1543-1546.

64 Germuth FG, Rodriguez E, Lorelle CA: Passive immune complex glomerulonephritis in mice: Models for various lesions found in human disease. II. Low avidity complexes and diffuse proliferative glomerulonephritis with subepithelial deposits. Lab Invest 1979;41: 366-372.

65 Lin CY: Hepatitis B virus associated membranous nephropathy: Clinical features, immunologic profiles and outcomes. Nephron 1990;55: 37-44.

66 Ito H, Hattori S, Matsuda I, Amamiya S, Hajikano H, Yoshizawa H, Miyakawa Y, Mayumi M: Deposition of hepatitis B e antigen in membranous glomerulonephritis: Identification by $\mathrm{F}\left(\mathrm{ab}^{\prime}\right)$ fragments of monoclonal antibody. Kidney Int 1984;26:338-341.

67 Hirose H, Udo K, Kojima M, Takahashi Y, Miyakawa $\mathrm{Y}$, Miyamoto $\mathrm{K}$, Yoshizawa $\mathrm{H}$, Mayumi M: Deposition of hepatitis B e antigen in membranous glomerulonephritis: Identification by $\mathrm{F}\left(\mathrm{ab}^{\prime}\right)_{2}$ fragments of monoclonal antibody. Kidney Int 1984;26:338-341.

68 Ito H, Hattori S, Matsuda I, M, Amamiya S, Hajikano $\mathrm{H}$, Yoshizawa $\mathrm{H}$, Miyakawa $\mathrm{Y}$, Mayumi M: Hepatitis B e antigen mediated membranous glomerulonephritis. Lab Invest 1981;44:214-220.

69 Lin CY, Lin CC, Chang GJJ, King CC: Defect of cell-mediated immune response against hepatitis B virus: An indication of pathogenesis of hepatitis B virus-associated membranous nephropathy. Nephron 1997;76:176-185.

70 Xin YH, Li JF, Yue EZ, Fanh YS, Xu RZ, Mu YG: In situ hybridisation of hepatitis B DNA in hepatitis B-associated glomerulonephritis. Pediatr Nephrol 1998;12:117-120.

71 Zhou SD, Zhang YE, Guo MY, Fang LJ, Zhang XR, Zhang M, Wu Z, Lin SY, Liao LT: The study of the significance of the appearance of $\mathrm{HbcAg}$ in glomerulonephritis. Chin J Nephrol 1995;11:104-106.

72 Eddleston ALWF, Mondelli M: Immunopathological mechanisms of liver cell injury in chronic hepatitis B virus infection. J Hepatol 1986;3(suppl 2):17-23. 
73 Dudley FJ, Fox RA, Sherlock S: Cellular immunity and hepatitis-associated Australia antigen liver disease. Lancet 1972;i:723-726.

74 London WT, Drew JS, Lustbader ED, Werner BG, Blumberg BS: Host responses to hepatitis $B$ infection in patients in a chronic haemodialysis unit. Kidney Int 1977;12:51-58.

75 Ramjee G: Studies of the mechanisms of proteinuria in kidney diseases of childhood; thesis, University of Natal, Durban, South Africa 1994.

76 Bhimma R, Hammond MG, Coovadia HM, Adhikari M, Connolly CA: HLA class I and II in black children with hepatitis B virus-associated membranous nephropathy. Kidney Int 2002;61:1510-1515.

77 Bhimma R, Hammond MG, Coovadia HM, Kramvis A, Adhikari M, Kew MC: HLA associations with $\mathrm{HBV}$ carriage and proteinuria. Pediatr Nephrol 2002;17:724-729.

78 Vaughan RW, Zurowska A, Moszkowska G, et al: HLA-DRB and -DQB1 alleles in Polish patients with hepatitis $B$ associated membranous nephropathy. Tissue Antigens 1998;52: 130-134.

79 Levy M, Kleinknecht C, Droz D, Dreuke T: Glomerular diseases and hepatitis B virus. Adv Nephrol 1982;11:341-370.

80 Lai KN, Tam JS, Lin HJ, Lai FM: The therapeutic dilemma of usage of corticosteroid in patients with membranous nephropathy and persistent hepatitis B surface antigenemia Nephron 1990;54:12-17.

81 Knieser MR, Jenis EH, Lowenthal DT, Bancroft WH, Burns W, Shalhoub R: Pathogenesis of renal disease associated with viral hepatitis. Arch Pathol 1974;97:193-200.

82 Guerra IL, Abraham AA, Kimmel PL, Sabnis SG, Antonovych T: Nephrotic syndrome associated with chronic persistent hepatitis $\mathrm{B}$ in a HIV antibody positive patient. Am J Kidney Dis 1987;10:385-388.

83 Cogan MG, Graber ML, Connor DG: Chronic active hepatitis and membranous nephropathy. Am J Gastroenterol 1977;68:386-391.

84 Kleinknecht C, Levy M, Peix A, Broyer M, Courtecuisse V: Membranous glomerulonephritis and hepatitis B surface antigenemia. $\mathrm{J}$ Pediatr 1979;95:946-952.

85 Kohler PF, Chronin RE, Hammond WS, Olin D, Carr RI: Chronic membranous glomerulonephritis caused by hepatitis antigen-antibody immune complexes. Ann Intern Med 1974;81: 448-451.

86 Hsu HC, Wu CY, Lin CY, Lin GJ, Chen CH, Huang FY: Membranous nephropathy in 52 hepatitis B surface antigen (HBsAg) carrier children in Taiwan. Kidney Int 1989;36:11031107.
87 Southwest Pediatric Nephrology Study Group: Hepatitis B surface antigenaemia in North American children with membranous glomerulonephropathy. J Pediatr 1985;106:571-557.

88 Furuse A, Hattori S, Terashima T, Karashima $\mathrm{S}$, Matsuda I: Circulating immune complex in glomerulopathy associated with hepatitis B virus infection. Nephron 1982;31:212-218.

89 Cadrobbi P, Bortolotti F, Zacchello G, Rinaldi R, Armigliato M, Realdi G: Hepatitis B virus replication in acute glomerulonephritis with chronic active hepatitis. Arch Dis Child 1985; 60:583-585.

90 Hoofnagle JH, Davis MD, Pappas C, Hanson RG, Peters M, Avigon MI, Waggoner JG, Jones EA, Seeff LB: A short course of prednisolone in chronic type B hepatitis. Ann Intern Med 1986; 104:12-17.

91 Lai FM, Tam JS, Li P, Lai KN: Replication of hepatitis B virus with corticosteriod therapy in hepatitis B virus-related membranous nephropathy. Virchows Arch Pathol Anat 1989; 414:279-284.

92 Haria M, Banfield P: Interferon- $\alpha 2 \mathrm{a}$ : A review of its pharmacological properties and therapeutic use in management of viral hepatitis. Drugs 1995;50:873-896.

93 Phillips TM: Interferon- $\alpha$ induces renal dysfunction and injury. Curr Opin Nephrol Hypertens 1996;5:380-383.

94 Belardelli F, Gressor I: The neglected role of type 1 interferon in the $\mathrm{T}$-cell response: Implications for its clinical use. Immunol Today 1996; 17:369-372.

95 Wakeel JA, Mitwalli A, Tarif N, Al-Mohaya S, Malik G, Khalil M: Role of interferon- $\alpha$ in the treatment of primary glomerulonephritis. Am J Kidney Dis 1999;33:1142-1146.

96 Wong DK, Cheung AM, Órourke K, Naylor CD, Detsky AS, Heathcote J: Effect of $\alpha$-interferon treatment in patients with hepatitis $\mathrm{B}$ e antigen positive chronic hepatitis B. A metaanalysis. Ann Intern Med 1993;119:312-323.

97 Lin CY: Treatment of hepatitis B virus-associated membranous nephropathy with recombinant $\alpha$-interferon. Kidney Int 1991;47:225230.

98 Bhimma R, Coovadia HM, Kramvis A, Adhikari M, Kew MC: Treatment of hepatitis B virus-associated nephropathy in black children. Pediatr Nephrol 2002; 17:393-399.

99 Perrillo RP, Schiff ER, Davis GL, Bodenheimer HC Jr, Lindsay K, Payne J, Dienstag JL, Obrien C, Tamburro C, Jacobson IM, Sampliner R, Feit D, Lefkowitch J, Kuhns M, Meschievitz C, Sanghvi B, Alrecht J, Gibas A and the Hepatitis Interventional Therapy Group: A randomised, controlled trial of interferon- $\alpha 2 b$ alone and after prednisone withdrawal for the treatment of chronic hepatitis B. N Engl J Med 1990;5:295-301.
100 Whittle HC, Pilkington J, Mendy M, Maine N, Fortuin M, Bunn J, Allison L, Howard C: Long-term efficacy of continuing hepatitis $\mathrm{B}$ vaccination in infancy in two Gambian villages. Lancet 1995;345:1089-1092.

101 Kew MC: Protective efficacy of hepatitis B vaccination. Lancet 1995;345:1065-1066.

102 Hsu HM, Chen DS, Chaung CH, Lu JC, Jwo DM, Lee CC, Lu HC, Cheng SH, Wang YF, Wang CY: Efficacy of a mass hepatitis B vaccination program in Taiwan. JAMA 1998; 260:2231-2235.

103 Tsen YJ, Chang MH, Hsu HY, Lee CY, Sung JL, Chen DS: Seroprevalence of hepatitis B virus infection in children in Taipei, 1989: Five years after a mass hepatitis B vaccination program. J Med Virol 1991;34:96-99.

$104 \mathrm{Wu}$ WS, Shao ZP: A review of hepatitis B immunisation. Chin J Vaccine Immun 1996; 2:61-66.

105 Line XM, Xu ZY, Ouyang PY, et al: Eight year survey for hepatitis B vaccine efficacy to newborns after universal immunisation. Chin J Exp Virol 1995;9:55-58.

106 Li RC, Yang JY, Wang SS, et al: The effect of hepatitis B vaccination on epidemiology of hepatitis virus. Chin J Vaccine Immun 1996; 2:56-60.

107 Safary A, Beck J: Vaccination against hepatitis B: Current challenges for Asian countries and future directions. J Gastroenterol Hepatol 2000;15:396-401.

108 Beasley RP, Hwang LY, Lin CC, Chien CS: Hepatocellular carcinoma and hepatitis B virus: A prospective study of 22,707 men in Taiwan. Lancet 1981;ii:1129-1133.

109 Chang MH, Chen CJ, Lai MS, Hsu HM, Wu TC, Kong MS, Liang DC, Shau WY, Chen DS: Universal hepatitis B vaccination in Taiwan and the incidence of hepatocellular carcinoma in children. N Engl J Med 1997;36: 1855-1859.

110 Zhao S, Xu Z, Lu Y: A mathematical model of hepatitis B virus transmission and its application for vaccination strategy in China. Int $\mathrm{J}$ Epidemiol 2000;29:744-752.

111 Zuckerman AJ: Prevention of primary liver cancer by immunisation. N Engl Med 1997; 26:1906-1907.

112 Lee CL, Ko YC: Hepatitis B vaccination and hepatocellular carcinoma in Taiwan. Pediatrics 1997;99:351-353.

113 Chen DS, Sung JL: Hepatitis B virus infection and chronic liver diseases in Taiwan. Acta Hepatogastroenterol 1978;25:423-430.

114 Kane M: Status of hepatitis V immunisation programmes in 1998. Vaccine 1998; 16(suppl):104-108.

115 The People of South Africa, Population census 1996. Statistics South Africa 1998, pp 4 22. 